\title{
Diammonium Glycyrrhizinate Mitigates Liver Injury Via Inhibiting Proliferation Of NKT Cells And Promoting Proliferation Of Tregs
}

This article was published in the following Dove Press journal:

Drug Design, Development and Therapy

\author{
Meixin Gao $\mathbb{D}^{1, *}$ \\ Xiulan $\mathrm{Li}^{2}$,* \\ Lingling $\mathrm{He} \mathbb{D}^{3}$ \\ Junru Yang $\mathbb{D}^{3}$ \\ Xiaohui Ye $\mathbb{D}^{3}$ \\ Fan Xiao ${ }^{4}$ \\ Hongshan Wei ${ }^{1-3}$ \\ 'Department of Gastroenterology, Peking \\ University Ditan Teaching Hospital, \\ Beijing 100015, People's Republic of \\ China; ${ }^{2}$ Center of Liver Diseases, Beijing \\ Ditan Hospital, Capital Medical \\ University, Beijing I000I5, People's \\ Republic of China; ${ }^{3}$ Department of \\ Gastroenterology, Beijing Ditan Hospital, \\ Capital Medical University, Beijing \\ I000 I5, People's Republic of China; \\ ${ }^{4}$ Institute of Infectious Diseases, Beijing \\ Ditan Hospital, Capital Medical \\ University, Beijing 1000I5, People's \\ Republic of China \\ *These authors contributed equally to \\ this work
}

Purpose: Diammonium glycyrrhizinate (DG) is a replacement for glycyrrhizic acid, which is used as a hepatic protector in clinical practice for most liver diseases. The potential role of immune response during autoimmune hepatitis-induced by concanavalin A (Con A) remains to be elucidated.

Methods: C57BL/6J mice were treated with two different doses of DG $(75$ and $200 \mathrm{mg} / \mathrm{kg}$ ) $2 \mathrm{hrs}$ before administering Con A. The mice were sacrificed after administering Con A for 0 , 6, and 24 hrs. Liver damage grade and serum alanine aminotransferase (ALT), aspartate aminotransferase (AST) and total bilirubin levels were evaluated. The expression level of cleaved-caspase 3 in liver was detected by Western blotting. Inflammatory cytokines such as tumor necrosis factor $\alpha$ (TNF- $\alpha$ ), interleukin-6 (IL-6), and interferon $\gamma$ (IFN- $\gamma$ ) in liver were detected by RT-PCR. Thymus, peripheral blood, spleen, and liver tissues were collected to analyze the percentages of NKT cells, subsets of $\mathrm{CD} 4^{+} \mathrm{CD} 25^{-} \mathrm{CD} 69^{+}$and $\mathrm{CD} 8^{+} \mathrm{CD} 69^{+} \mathrm{T}$ cells, and subsets of regulatory $\mathrm{T}$ cells (Tregs).

Results: Our results revealed that DG pre-treatment significantly decreased the serum ALT and AST levels and improved the histological damage in Con A-induced autoimmune liver injury. Pre-treatment with DG down-regulated the inflammatory cytokines upon challenge with Con A. The DG pre-treatment inhibited the apoptosis of T lymphocytes in the thymus. Further, it effectively suppressed the proliferation of $\mathrm{CD} 4{ }^{+} \mathrm{CD} 25^{-} \mathrm{CD} 69^{+}$and $\mathrm{CD} 8^{+} \mathrm{CD} 69^{+}$ subsets in the peripheral blood and spleen. In addition, the DG pretreatment significantly downregulated the frequency of NKT cells, while upregulating the frequency of Tregs in the liver.

Conclusion: We believe that the potential protective effect of DG against Con A-induced hepatitis may be partially attributed to its inhibitory activities on inflammatory cytokines in the livers, lymphocyte apoptosis in the thymus, NKT cells proliferation, and activation of $\mathrm{CD}^{+} \mathrm{T}$ cells; further, there may also be a possibility of DC promoting Tregs proliferation.

Keywords: autoimmune hepatitis, concanavalin A, diammonium glycyrrhizinate, NKT cells, regulatory $\mathrm{T}$-cell

\section{Introduction}

Autoimmune hepatitis (AIH) - a chronic inflammatory liver injury - is characterized by interface hepatitis, hyper-globulinemia, appearance of autoantibodies, and immune imbalance. ${ }^{1}$ There are complex etiologies of AIH that include genes, environment, and immune disorders. ${ }^{2}$ Patients with AIH who miss timely treatment may progress to terminal liver diseases. ${ }^{3}$ Although the diagnostic guidelines for AIH have been proposed previously, there are still some problems. ${ }^{4,5}$ The main
Correspondence: Hongshan Wei Department of Gastroenterology, Beijing Ditan Hospital, Capital Medical University, No. 8, Jingshun East Street, Chaoyang District, Beijing 100015, People's Republic of China

Email drwei@ccmu.edu.cn 
challenge is that the etiology and molecular mechanisms of AIH remain unclear; however, it is known that the imbalance between regulatory $\mathrm{T}$ cells (Tregs) and effector lymphocytes plays an important role in the occurrence of AIH. ${ }^{5}$ Some studies indicated that differentiation of T cells into effector $\mathrm{T}$ cells promoted the fatal progression of AIH in a mouse model. ${ }^{6}$ Other studies suggested that Tregs from AIH patients were more prone to acquire effect properties than those from healthy people; after treatment, Tregs from AIH patients exhibited a decreasing trend in both member and function. ${ }^{7}$ Natural killer T (NKT) cells account for about $20-35 \%$ of the total lymphocytes in the liver of mice and about $10-15 \%$ of total lymphocytes in the human liver; ${ }^{8}$ studies focused on NKT cells indicate that they play a pro-inflammatory and pro-apoptosis role in liver diseases. ${ }^{8-10}$ The NKT cells are one of the most important type of effector cells related to immune liver injury, ${ }^{11}$ and the imbalance between Tregs and NKT cells distinctly trigger the development of autoimmune responses. ${ }^{12}$ These studies suggested that once Tregs lose the capacity of inhibiting the proliferation and function of effector $\mathrm{T}$ cells, the disease will occur and progress rapidly.

Diammonium glycyrrhizinate (DG) —an ammonium salt preparation of 18-alpha-glycyrrhizin-exhibits antiinflammation, immunomodulation, anti-anaphylaxis, and membranous protection effects. ${ }^{13-15}$ Currently, the family of glycyrrhizin is used in clinical practice as an effective liver protector against most hepatic diseases such as chronic viral hepatitis, ${ }^{16}$ drug-induced liver injury, ${ }^{17}$ nonalcoholic fatty liver disease, ${ }^{18,19}$ autoimmune hepatitis, ${ }^{20}$ and hepatocellular carcinoma. ${ }^{21}$ Previous studies concluded that DG exerted a protective effect by downregulating inflammation cytokines, suppressing the NF- $\mathrm{KB}$ pathway, and restoring superoxide dismutase. ${ }^{22,23}$ However, the potential protection mechanisms of DG in AIH are still not clear.

In this study, we established a concanavalin A (Con A)induced autoimmune hepatitis model to identify the protective role of DG in AIH and elucidate its potential mechanisms. We investigated NKT cells and $\mathrm{CD} 4^{+} \mathrm{CD} 25^{+} \mathrm{Foxp}^{+}$Tregs from the liver, and the $\mathrm{CD} 4^{+} \mathrm{CD} 25^{-} \mathrm{CD} 69^{+}$and $\mathrm{CD} 8^{+} \mathrm{CD} 69^{+}$subsets from the periphery blood, spleen, and liver because the imbalance of the immune system is considered a significant factor in AIH progression, ${ }^{5-7,24,25}$ and CD69 has gained considerable research attention owing to its complex inflammatory and immune-regulatory properties. ${ }^{26}$ The present study helped us improve our understanding of the mechanism of DG protection in an autoimmune liver injury.

\section{Materials And Methods}

\section{Animals And Drugs}

Six-to-eight-weeks-old male C57BL/6J mice were procured from the Animal Center of Health and Science Center, Peking University (Beijing, China), where mice were kept in specific pathogen-free conditions. All mice were adapted to standard laboratory conditions (regularly $12 \mathrm{hrs} \mathrm{lights/dark}$ cycle, $21 \pm 2^{\circ} \mathrm{C}$ ) for at least one week. DG was offered by ChiaTai-Tianqing Pharmaceutical Co., Ltd. (Nanjing, China), and it was stored at room temperature. Further, it was diluted to a special concentration $(10 \mathrm{mg} / \mathrm{mL})$ with $0.9 \%$ saline and was injected intraperitoneally into the mice just single shot $2 \mathrm{hrs}$ before the experiment. The animal experiments were supported by the National Institutes of Health Guide for the Care and Use of Laboratory Animals, National Institutes of Health. And the study was approved by the ethics committee of Animal Experiments and Experimental Animal Welfare Committee of Capital Medical University on December 12, 2017 [number AEEI-2017-136]. All experimental manipulations were performed in the Institute of Infectious Diseases, Beijing Ditan Hospital (Beijing, China).

\section{Con A-Induced Hepatitis}

The animals were intravenously injected with Con A ( $20 \mathrm{mg} /$ $\mathrm{kg}$ ) to establish immune-mediated liver-injury models. The experimental mice were pre-treated with DG intraperitoneal injections at dosages of $75 \mathrm{mg} / \mathrm{kg}$ and $200 \mathrm{mg} / \mathrm{kg},{ }^{13,15,17} 2 \mathrm{hrs}$ before the Con A injection. The control mice were injected with an equal volume of saline. The mice were then sacrificed after administering Con A for 0, 6, and $24 \mathrm{hrs}$. Meanwhile, we collected the serum of the animals for transaminases tests, and the blood, spleen, thymus, and a part of liver for subsequent flow cytometry analyses. The other part of liver specimens was used to assess the level of pathological injury. All the abovementioned experiments were performed in triplicate.

\section{Serum Level Of Transaminases}

Blood samples were collected after mice were sacrificed, and the samples were centrifuged at $3000 \times g$ for 10 mins to obtain the serum. Next, the levels of serum alanine aminotransferase (ALT), aspartate aminotransferase (AST), and total bilirubin were measured using a biochemical kit (Sichuan Maccura Biotechnology, Sichuan, China).

\section{Liver Histological Assessment}

Livers from the mice were fixed in formalin. After paraffin embedding, sectioning, and hematoxylin-eosin staining, 
thin tissue sections were acquired and used to investigate the liver injury. The revised Knodell protocol was adopted to assess liver damage. ${ }^{27}$ In brief, 0 indicated no inflammation or necrosis; 1 , confluent or intralobular inflammation; 2, slight piecemeal necrosis or focal necrosis; 3, medium confluent inflammation and piecemeal necrosis, or serious focal necrosis; and 4, serious confluent inflammation and piecemeal necrosis, or bridging necrosis. The damage score was evaluated in a blinded manner.

\section{Western Blot Analysis}

Liver tissues were lysed by RIPA lysis buffer (Solarbio Science \& Technology Co. Ltd., Beijing, China). The proteins were separated by sodium dodecyl sulfate polyacrylamide gel electrophoresis (SDS-PAGE), and transferred to polyvinylidene fluoride (PVDF) membranes. The following antibodies were used to incubate the proteins: anti- $\beta$-actin antibody $(1: 1000$ dilution; Cell Signaling Technology, Danvers, MA, USA), anti-caspase3 antibody (1:1000 dilution; Cell Signaling Technology, Danvers, MA, USA). Then, they were incubated with the second conjugated immunoglobulins (ZF-0316; ZSGBBIO Co. Ltd., Beijing, China). Finally, the proteins were detected by the method of enhanced chemiluminescence (ECL).

\section{Reverse Transcription-polymerase Chain Reaction (RT-qPCR) Analysis}

Liver tissues were lysed by TRIzol (Invitrogen, Carlsbad, CA, USA) for total RNA extraction. Reverse transcription of total RNA into cDNA was used by a TransScript First-Strand cDNA Synthesis SuperMix (TransGen Biotech, Beijing, China). RT-PCR was performed using a PrimeScriptTM RT reagents kit (TaKaRa, Shiga, Japan) following the manufacturer's instructions. GAPDH was determined as a reference gene and the relative levels of target genes were calculated using the 2- $\Delta \Delta \mathrm{CT}$ method. The sequences of the primers used for PCR are shown as following: GAPDH Forward: TGGCCTTCCGTGTTCCTAC, GAPDH Reverse: TGGCCTT CCGTGTTCCTAC; TNF- $\alpha$ Forward: CTGAACTTCGGGGT GATCGG, TNF- $\alpha$ Reverse: GGCTTGTCACTCGAATTTT GAGA; IL-6 Forward: TAGTCCTTCCTACCCCAATTT CC, IL-6 Reverse: TTGGTCCTTAGCCACTCCTTC; IFN- $\gamma$ Forward: ATGAACGCTACACACTGCATC, IFN- $\gamma$ Reverse: CCATCCTTTTGCCAGTTCCTC.

\section{Flow Cytometry}

We harvested the blood, spleen, liver, and thymus when the mice were sacrificed. After lysing blood, levigating tissues, centrifuging, and filtrating, single-cell suspensions were finally obtained. For liver interstitial cells, we performed density-gradient centrifugation using Percoll. Next, these single-cell suspensions were stained with the following fluorescent monoclonal antibodies CD69-FITC, CD25-PE, CD8PerCP, and CD4-APC for peripheral blood mononuclear cells (PBMC), splenocytes, and liver; Annexin V-FITC, CD8-PE, 7aad-PerCP, and CD4-APC for thymocytes; and NK1.1-FITC, CD3-PE, FasL-PerCP, CD4-FITC, Foxp3-PE, and $\mathrm{CD} 25-\mathrm{PerCP}$ for liver interstitial cells. All fluorescent monoclonal antibodies were purchased from eBioscience company (San Diego, CA, USA). The frequencies of our expected subsets were detected by flow cytometry (FACS Caliber, BD Bioscience Company, USA).

\section{Statistical Analysis}

Quantitative data were expressed as mean \pm standard deviation (SD). We performed statistical analysis with SPSS 19.0. The one-way ANOVA and Kruskal-Wallis test were used to analyze most of our data. Statistical significance was determined as $P<0.05$.

\section{Results}

\section{DG Pre-Treatment Alleviated}

\section{Concanavalin A-Induced Liver Damage}

To investigate the effect of DG on Con A-induced hepatitis, we tested the serum liver enzymes and total bilirubin under Con A administration at different time-points with or without DG pre-treatment. The results showed that DG inhibited the increase of both ALT and AST levels, especially after Con A administration for $24 \mathrm{hrs}$ (Figure 1A and B). Compared with only Con A administration (890.42 $\pm 216.32 \mathrm{U} / \mathrm{L})$, mice that underwent DG pretreatment $(75 \mathrm{mg} / \mathrm{kg}$ and $200 \mathrm{mg} / \mathrm{kg}$ ) exhibited lower ALT levels after administering Con A for 24 hrs (241.71 $\pm 106.09 \mathrm{U} / \mathrm{L}, P=0.007 ; 265.62 \pm 82.43 \mathrm{U} / \mathrm{L}$, $P=0.032$, Figure 1A). A similar decreasing trend was observed in AST levels (823.71 \pm 214.21 in Con A vs $220.06 \pm 85.84$ in Con A+DG $75 \mathrm{mg} / \mathrm{kg}, P=0.008$; and vs $244.70 \pm 79.09$ in Con $\mathrm{A}+\mathrm{DG} 200 \mathrm{mg} / \mathrm{kg}, P=0.022$, Figure 1B). However, the total bilirubin was not significantly different between control group and DG pre-treatment groups (Figure 1C). Next, we compared the pathological injuries caused to the livers in these different treatment groups with H\&E staining (Figure 1D). The results showed 

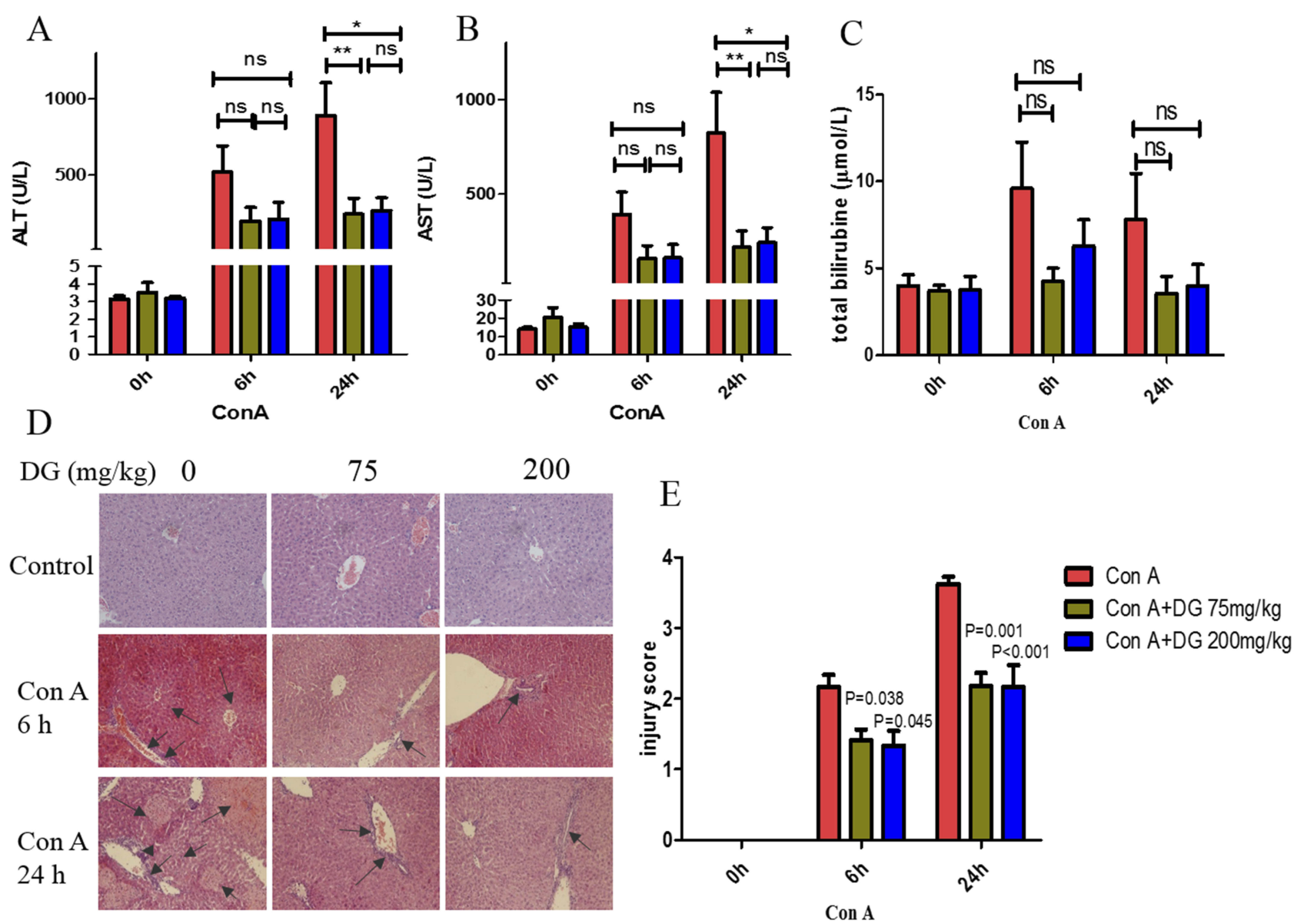

Figure I Pre-treatment with DG improves the liver injury upon challenge with Con A. Levels of serum alanine aminotransferase (ALT) (A) aspartate aminotransferase (AST) (B) and total bilirubin (C) in mice treated with different doses of DG before and after Con A administration for 6 hrs and 24 hrs. (D) H\&E staining for livers (200x). The black arrows indicate the inflammatory infiltration and necrosis areas. (E) The injury score evaluation was in accordance with pathological staining. Data in the graph indicate $P$-values between the DG pretreatment and control groups. ${ }^{*}, * *$ mean $P<0.05$ and $P<0.01$, respectively. $N=8$ for each group. This experiment was performed in triplicate.

that livers without DG pretreatment exhibited a more significant disorder of hepatic lobule, a larger necrosis size, and more inflammatory cells infiltration. The liver injury score was assessed using the standard mentioned above. As shown in Figure 1E, the damage score of the control group was also higher than that of the groups that received DG pretreatment.

To further compare the liver injury between the control group and DG pre-treatment group in Con Ainduced autoimmune injury, we detected the expression level of cleaved-caspase 3 in liver tissues by Western blotting. As shown in Figure 2, there was no significant difference between the control group and DG pre-treatment group before and after Con A administrated for 6 hrs; however, after Con A administration for $24 \mathrm{hrs,} \mathrm{the}$ expression level of cleaved-caspase 3 in DG pre-treatment group (both $75 \mathrm{mg} / \mathrm{kg}$ and $200 \mathrm{mg} / \mathrm{kg}$ ) exhibited a marked decreasing trend in comparison with that of control group (Figure 2C).

\section{Pre-Treatment With DG Inhibited The Levels Of Inflammatory Cytokines}

It is well known that inflammatory cytokines play a crucial role in autoimmune response. To investigate the effect of pre-treatment with DG on the levels of inflammatory cytokines in Con A-induced liver injury, we compared the mRNA levels of TNF- $\alpha$, IL-6, and IFN- $\gamma$ in liver tissues by RT-PCR. Our results showed that pre-treatment with DG significantly down-regulated the mRNA level of TNF$\alpha$ after administrating with Con A for 24 hrs (Figure 3A). The mRNA level of IL-6 from the groups of DG pretreatment exhibited a decreasing trend in comparison with that of the group of Con A administrating alone 


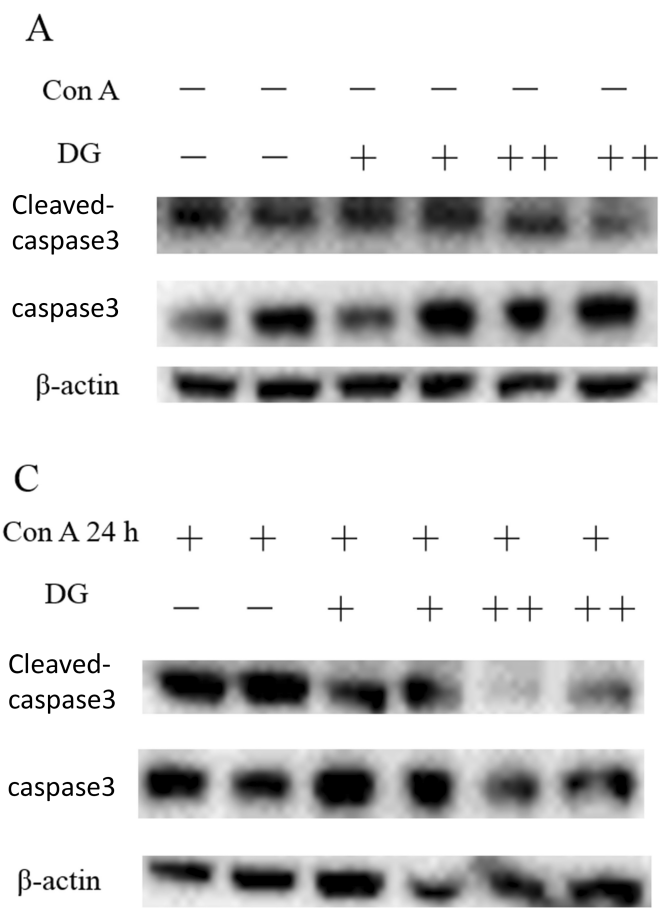

$\mathrm{B}$

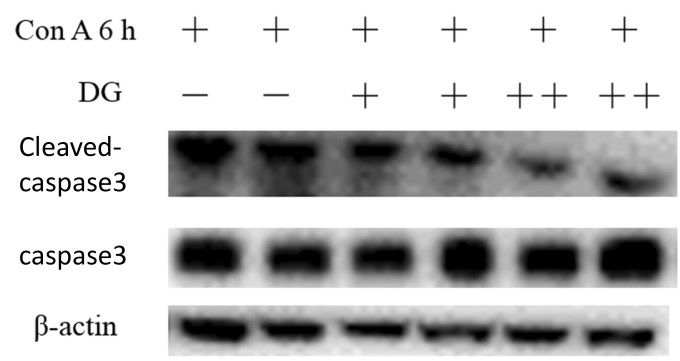

Figure 2 Pre-treatment with DG inhibited the expression level of cleaved-caspase 3 in Con A-induced liver injury. (A) The expression levels of cleaved-caspase 3 with or without pre-treatment of DG at the baseline. (B), (C) The expression levels of cleaved-caspase 3 with or without pre-treatment of DG after Con A administration for 6 and $24 \mathrm{hrs}$, respectively. "+" and "++" of DG mean $75 \mathrm{mg} / \mathrm{kg}$ and $200 \mathrm{mg} / \mathrm{kg}$, respectively. $\mathrm{N}=2$ for each group. This experiment was performed in triplicate.

(Figure 3B). However, as for the level of IFN- $\gamma$, there was no significant difference between the control group and DG pre-treatment groups (Figure 3C).

\section{DG Pre-Treatment Suppressed CD4 ${ }^{+}$ And $\mathrm{CD}^{+} \mathrm{T}$ Cells Apoptosis In The Thymus}

The immune response of $\mathrm{T}$ lymphocytes is a primary defense in Con A-induced liver injury. As the thymus is the most important place for $\mathrm{T}$ lymphocytes development, we wondered whether lymphocytes apoptosis in the thymus could be involved in the protection mechanism of DG in Con Ainduced liver injury. We analyzed the apoptosis levels of $\mathrm{CD}^{+}$and $\mathrm{CD} 8^{+}$single positive $\mathrm{T}$ cells in the thymus before and after administering Con A for 6 and 24 hrs with or without DG pretreatment (Figure 4A). Interestingly, in comparison with the only Con A treatment, $\mathrm{CD}^{+}{ }^{+} \mathrm{T}$ cells from the Con $\mathrm{A}+75 \mathrm{mg} / \mathrm{kg}$ DG group showed a lower apoptosis phenomenon after administering Con A for $24 \mathrm{hrs}(21.30 \pm 1.79$ in Con A vs $14.78 \pm 2.20$ in Con A + DG $75 \mathrm{mg} / \mathrm{kg}, P=0.025$; and vs $14.54 \pm 1.62$ in Con A + DG $200 \mathrm{mg} / \mathrm{kg}, P=0.051$, Figure $4 \mathrm{~B}$ ). In addition, the same result was also obtained for $\mathrm{CD}^{+} \mathrm{T}$ cells. After Con A administration for $24 \mathrm{hrs}$, the apoptosis level of $\mathrm{CD}^{+} \mathrm{T}$ cells in the $\mathrm{DG}$ pretreatment group significantly decreased compared with that in the control group $(20.21 \pm 1.70$ in Con A vs $14.63 \pm 1.93$ in the Con A + DG $75 \mathrm{mg} / \mathrm{kg}, P=0.035$; and vs $13.76 \pm 1.77$ in Con A + DG $200 \mathrm{mg} / \mathrm{kg}, P=0.043$. Figure 4C).

\section{DG Inhibits The Proliferation Of $\mathrm{CD} 8^{+} \mathrm{CD} 69^{+}$And $\mathrm{CD} 4^{+} \mathrm{CD} 25^{-} \mathrm{CD} 69^{+}$ Subsets In Peripheral Blood And Spleen}

As CD69 is considered an important immune modulatory molecule, we wondered whether CD69 accounts for the protection effect of DG in Con A-induced autoimmune hepatitis. ${ }^{26}$ We investigated the frequencies of $\mathrm{CD}^{+} \mathrm{CD} 69^{+}$ $\mathrm{T}$ cell subsets in the peripheral blood, spleen, and liver at different time-points with or without DG pretreatment (Figure 5A). After Con A was administrated, the frequency of the $\mathrm{CD} 8^{+} \mathrm{CD} 69^{+}$subset significantly increased in the peripheral blood and spleen. Interestingly, we found that DG pretreatment inhibited the proliferation of the $\mathrm{CD}^{+} \mathrm{CD} 9^{+}$subset in the splenocytes after Con A administration for $24 \mathrm{hrs}(92.96 \pm 1.24$ in Con A vs $66.71 \pm 4.78$ in Con A + DG $75 \mathrm{mg} / \mathrm{kg}, P<0.001$; and vs $67.84 \pm 5.79$ in Con $\mathrm{A}+\mathrm{DG} 200 \mathrm{mg} / \mathrm{kg}, P=0.001$, Figure 5C). A similar result also appeared in peripheral blood after Con A administration for 6 hrs (19.92 \pm 2.91 in Con A vs $9.99 \pm 2.71$ in Con A + DG 
A

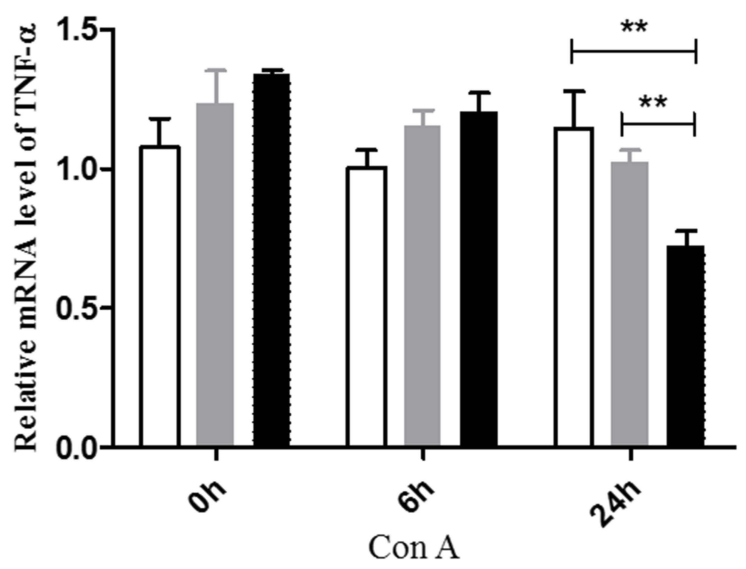

C

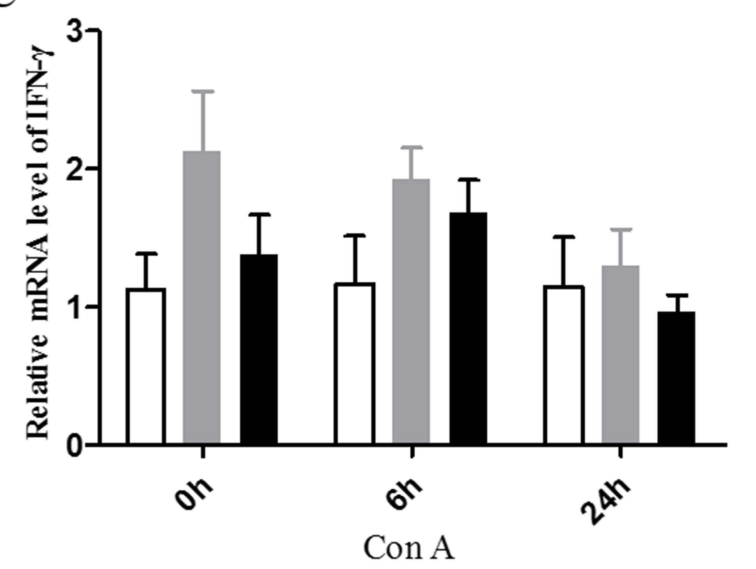

B

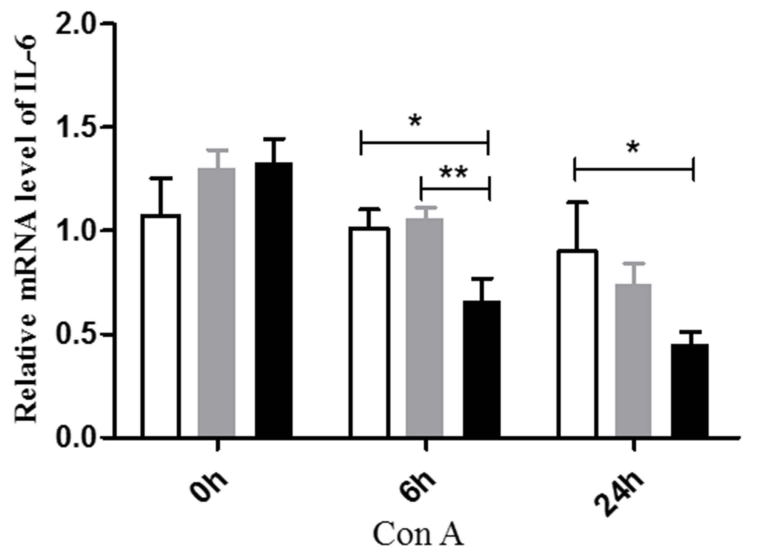

Con $A$

Con A + DG 75 mg/kg

Con A + DG 200 mg/kg

Figure 3 Pre-treatment with DG down-regulated the mRNA levels of inflammatory cytokines in Con A challenged mice. (A-C) The relative mRNA levels of TNF- $\alpha$, IL-6, and IFN- $\gamma$, respectively. ${ }^{*}$, $*$ mean $P<0.05$ and $P<0.0$ I, respectively. $N=4$ for each group. This experiment was performed in triplicate.

$75 \mathrm{mg} / \mathrm{kg}, P=0.022$, Figure 5B). However, no statistical differences in the liver were observed between the control group and the Con A + DG group in our model (Figure 5D).

For the CD4 subset, we detected the frequencies of the $\mathrm{CD} 4{ }^{+} \mathrm{CD} 25^{-} \mathrm{CD} 69^{+}$subset in blood, spleen, and liver at different time-points with or without DG pretreatment. Compared with the control group in the peripheral blood $(7.90 \pm 0.76)$, the frequency of the $\mathrm{CD} 4^{+} \mathrm{CD} 25^{-} \mathrm{CD} 69^{+}$subset appeared to show a decreasing trend after Con A administration for $6 \mathrm{hrs}$ in the DG-pretreated group at dosages of 75 $\mathrm{mg} / \mathrm{kg}(3.80 \pm 0.97, P=0.003)$ and $200 \mathrm{mg} / \mathrm{kg}(3.72 \pm 0.89$, $P=0.004$, Figure 5E). Further, after Con A administration for $24 \mathrm{hrs}$, the result was found to be parallel with that of Con A administered for $6 \mathrm{hrs}(10.01 \pm 1.16$ in Con A vs $2.96 \pm$ 0.15 in Con A + DG $75 \mathrm{mg} / \mathrm{kg}, P<0.001$; and vs $4.06 \pm 0.48$ in Con A + DG $200 \mathrm{mg} / \mathrm{kg}, P=0.034$, Figure 5E). The frequency of the $\mathrm{CD} 4^{+} \mathrm{CD} 25^{-} \mathrm{CD} 69^{+}$subset in the spleen showed a similar decreasing trend at $24 \mathrm{hrs}$ after Con A administration $(11.47 \pm 1.81$ in Con $\mathrm{A}$ vs $4.84 \pm 1.18$ in
Con A + DG $75 \mathrm{mg} / \mathrm{kg}, P=0.002$; and vs $3.80 \pm 0.36$ in Con A + DG $200 \mathrm{mg} / \mathrm{kg}, P=0.001$, Figure 5F). However, it was shown that the DG pretreatment upregulated the percentage of the $\mathrm{CD} 4^{+} \mathrm{CD} 25^{-} \mathrm{CD} 69^{+}$subset in the liver after Con $\mathrm{A}$ administration for $6 \mathrm{hrs}(14.53 \pm 1.011$ in Con A vs $18.10 \pm$ 0.694 in Con A+DG $200 \mathrm{mg} / \mathrm{kg}, P=0.0236$, Figure 5G).

\section{DG Promoted CD4 ${ }^{+} \mathrm{CD} 25^{+}$Foxp $3^{+}$Tregs Proliferation While Inhibiting NKT Cells \\ Proliferation}

Because NKT cells obviously account for Con A-induced autoimmune liver injury, regulatory $\mathrm{T}$ cells are well regulated to maintain immune homeostasis. ${ }^{8}$ We detected Tregs and NKT cells in the liver. As shown in our results, the DG pretreatment did not affect Tregs at the baseline (Figure $6 \mathrm{~B})$, but it markedly downregulated the percentage of NKT cells $(28.47 \pm 7.41$ in Con A vs $17.85 \pm 2.33$ in Con A + DG $75 \mathrm{mg} / \mathrm{kg}, P=0.068$; and vs $16.5 \pm 1.28$ in Con A + DG 200 

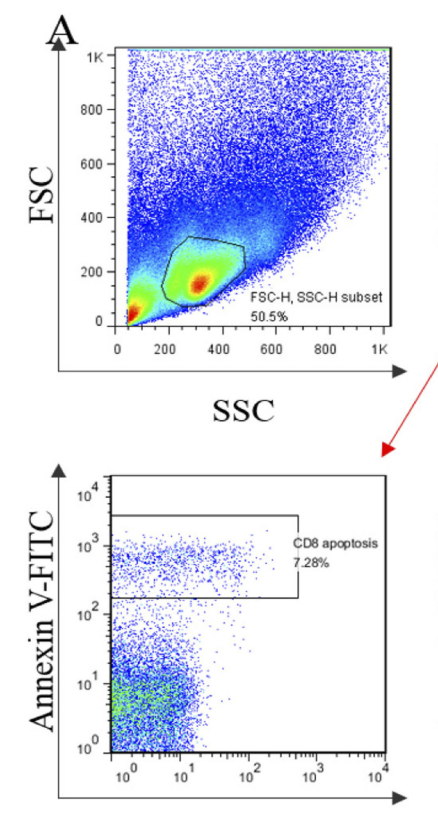

7aaD-PerCP
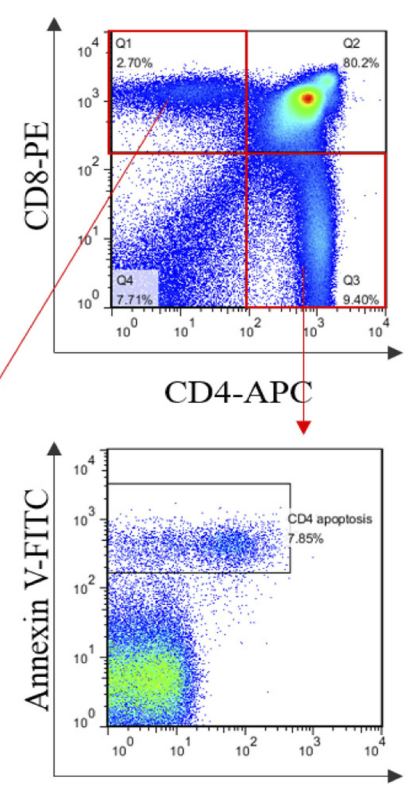

7aaD-PerCP
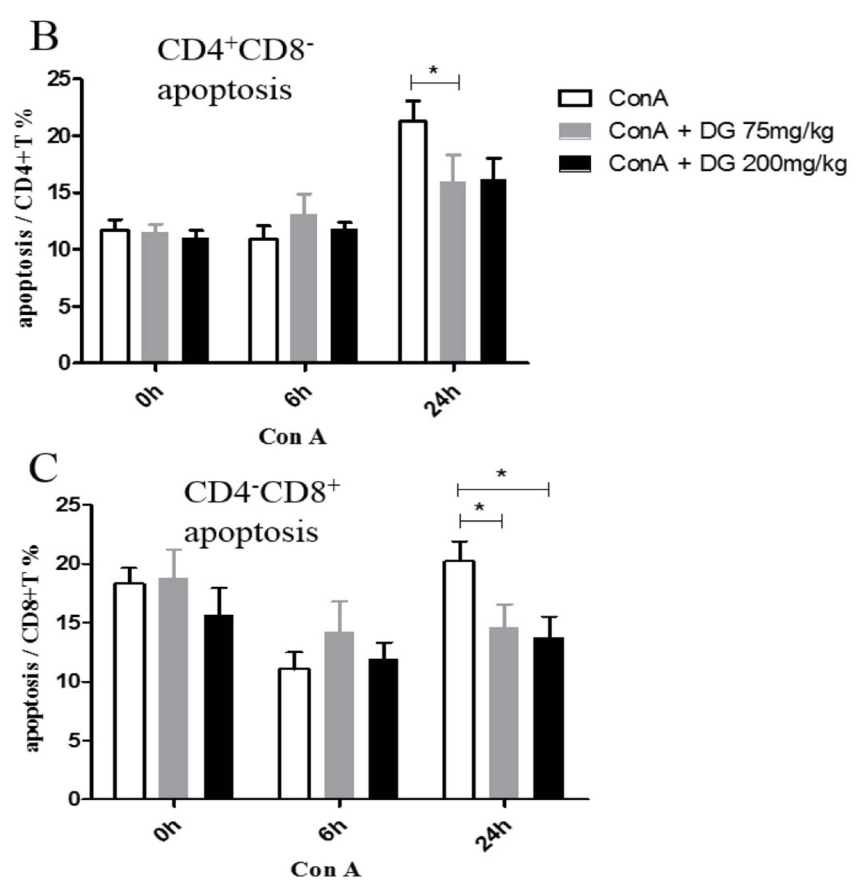

Figure 4 Levels of apoptosis of $C D 4^{+} \mathrm{CD} 8^{-}$and $\mathrm{CD} 4^{-} \mathrm{CD} 8^{+}$cells in the thymus were decreased with pre-treatment of DG in Con A challenged mice. (A) Analysis of $\mathrm{T}$ lymphocytes apoptosis levels in the thymus. (B) The apoptosis level of $C D 4^{+} C D 8^{-}$cells in Con A-induced immune injury with or without DG pre-treatment. (C) The apoptosis level of $\mathrm{CD}^{-} \mathrm{CD} 8^{+}$cells in Con A-induced immune injury with or without DG pre-treatment. $*$ indicates $P<0.05$. $\mathrm{N}=8$ for each group. This experiment was performed in triplicate.

$\mathrm{mg} / \mathrm{kg}, P=0.015$, Figure 6D), and the expression levels of FasL on the surface of the NKT cells $(3.52 \pm 1.40$ in Con A vs $1.029 \pm 0.482$ in Con A + DG $75 \mathrm{mg} / \mathrm{kg}, P=0.04$; and vs $1.35 \pm 0.508$ in Con A + DG $200 \mathrm{mg} / \mathrm{kg}, P=0.028$, Figure $6 \mathrm{E})$. After Con A administration, the frequency of Tregs significantly increased. Interestingly, we found that DG pretreatment significantly enhanced the increasing effect of Tregs after Con A administration for $6 \mathrm{hrs}(3.54 \pm 0.256$ in Con A vs $5.56 \pm 1.16$ in Con A + DG $75 \mathrm{mg} / \mathrm{kg}, P=0.028$; and vs $5.18 \pm 1.06$ in Con A + DG $200 \mathrm{mg} / \mathrm{kg}, P=0.023$, Figure 6B). NKT cells were significantly decreased compared with the control group after Con A administration for 24 hrs $(8.003 \pm 2.614$ in Con A vs $4.695 \pm 1.611$ in Con A + DG $75 \mathrm{mg} / \mathrm{kg}, P=0.036$, Figure 6D). Meanwhile, the expression level of FasL on the surface of NKT cells also showed a marked decreasing trend in the Con A + DG $75 \mathrm{mg} /$ $\mathrm{kg}$ group in comparison with the control group after Con A administration for $24 \mathrm{hrs}(4.59 \pm 1.72$ in Con A vs $2.24 \pm$ 0.887 in Con A + DG $75 \mathrm{mg} / \mathrm{kg}, P=0.022$, Figure 6E).

\section{Discussion}

Diammonium glycyrrhizinate has been used as a liver protector for decades. However, its protective effect on AIH and the underlying molecular mechanism remain to be elucidated. In the present study, we found that DG pre-treatment could reduce serum ALT and AST levels and alleviate liver pathological damage in Con A-induced hepatitis. Histology staining showed mice that accepted DG pre-treatment had fewer inflammatory cells infiltration, lower hepatic cords destruction, and fewer necrosis sizes compared with that of administrating with Con A alone. Further detections indicated that pre-treatment with DG down-regulated the expression levels of cleaved-caspase 3 and the mRNA levels of inflammatory cytokines in Con A-induced liver injury. All these results indicated that DG plays a significant protective role in our experimental autoimmune hepatitis model. The potential mechanism may be related to the suppression effect of DG on the $\mathrm{CD}^{+} 9^{+}$subset proliferation of $\mathrm{T}$ lymphocytes, and in disrupting the balance of regulatory T cells and NKT cells.

Previous studies have shown that Con A injection induces apoptosis. ${ }^{28,29} \mathrm{We}$ detected $\mathrm{T}$ cell apoptosis from the thymus in Con A-induced hepatitis with or without DG pretreatment. For our results, the apoptosis of $\mathrm{CD}^{+}$and $\mathrm{CD}^{+} \mathrm{T}$ lymphocytes in the thymus were consistent with previous studies mentioned above, which showed Con A increased apoptosis. Furthermore, DG downregulated cell apoptosis for both $\mathrm{CD}^{+}$and $\mathrm{CD}^{+} \mathrm{T}$ cells in the Con Ainduced hepatitis model, which implied another protective 


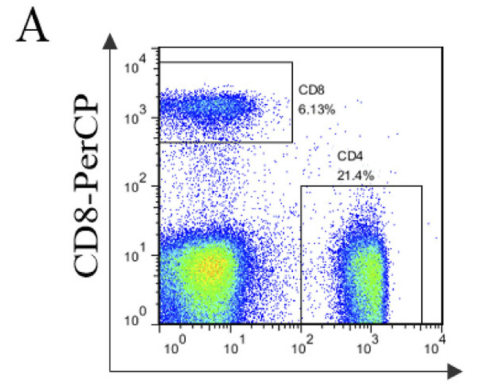

CD4-APC
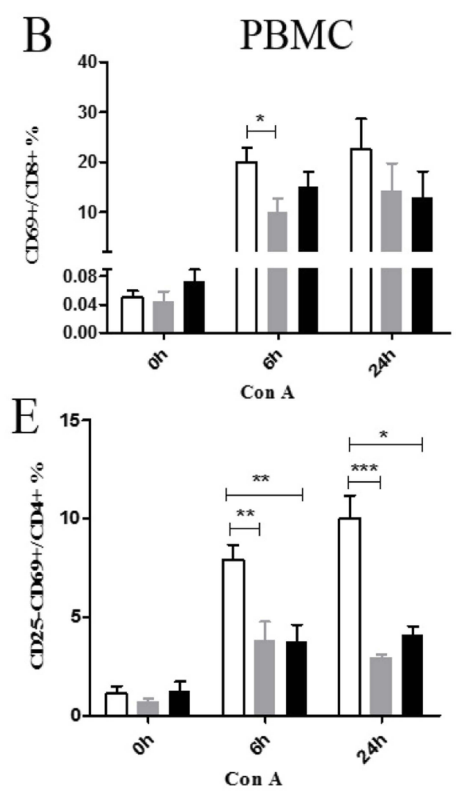

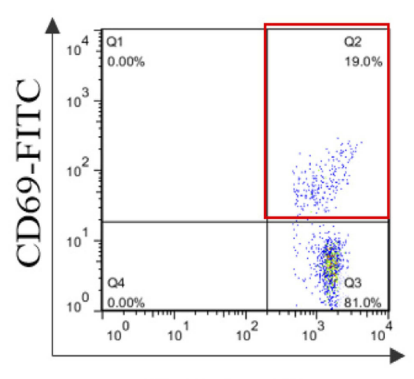

CD8-PerCP
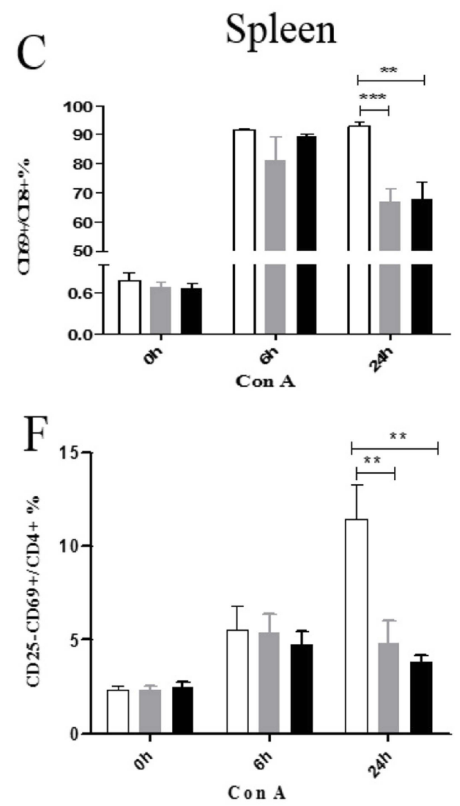

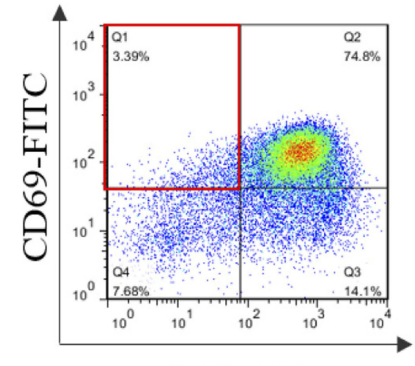

CD25-PE
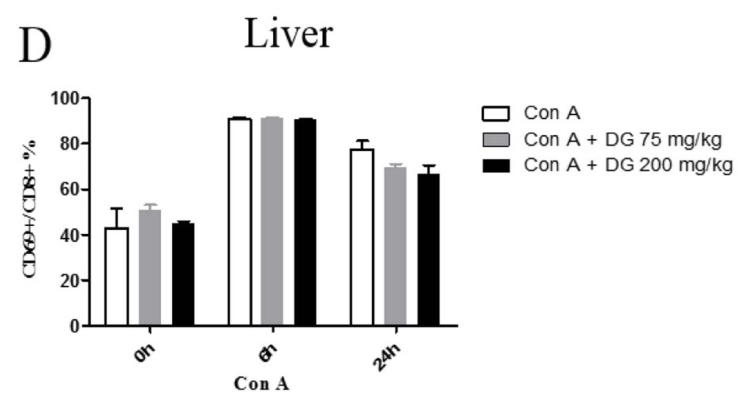

G

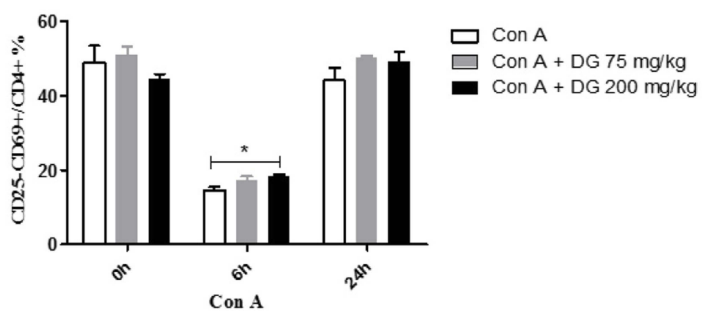

Figure 5 Pre-treatment with DG suppressed the activation levels of CD4 ${ }^{+}$and CD8 ${ }^{+} \mathrm{T}$ cells. (A) Analysis of T lymphocytes activation levels. (B-D) The percentages of the $\mathrm{CD} 8^{+} \mathrm{CD} 69^{+}$subset from the PBMC, spleen, and liver, respectively, in Con A-induced immune injury with or without DG pre-treatment. (E-G) The percentages of the $\mathrm{CD} 4^{+} \mathrm{CD} 25^{-} \mathrm{CD} 69^{+}$subset from the PBMC, spleen, and liver, respectively, in Con A-induced immune injury with or without DG pre-treatment. *, **, and *** mean $P<0.05$, $P<0.01$, and $P<0.001$, respectively. $N=8$ for each group. This experiment was performed in triplicate.

mechanism of DG in Con A-induced liver injury. It is reported that the destruction of immune tolerance was involved in negative selection, and it induced the apoptosis of auto-reactive thymocytes. ${ }^{30}$ In this regard, we speculated that DG might mitigate the destruction of immune tolerance and reduce apoptosis in the thymus sequentially.

CD69 is a membrane receptor from the family of II Ctype lectins and is known as an early leukocyte activation antigen. CD69 has a low expression in resting cells and is rapidly induced after cells activation. ${ }^{31}$ Our data showed a decreasing trend of the $\mathrm{CD} 8^{+} \mathrm{CD} 69^{+}$subset in DG-pretreated mice compared with that of the control group. Based on this result, we speculated that $\mathrm{CD} 8{ }^{+} \mathrm{CD} 69^{+} \mathrm{T}$ lymphocytes play a pro-inflammation role in our model, and DG reduces liver injury probably because it downregulates the $\mathrm{CD} 8^{+} \mathrm{CD} 69^{+}$ subset. Previous studies also showed a similar result in different disease models; for example, García-Monzón et $\mathrm{al}^{32}$ detected that the $\mathrm{CD} 8^{+} \mathrm{CD} 69^{+} \mathrm{T}$ cell subset was involved in the inflammation progression of chronic viral active hepatitis. Some researchers ${ }^{33}$ also found that enrichment of $\mathrm{CD} 8^{+} \mathrm{CD} 69^{+}$in female adipose tissue may contribute to cardiovascular diseases. Murata et $\mathrm{al}^{34}$ established an arthritis model that can be induced by anti-type II collagen antibodies, which showed that $\mathrm{CD} 69^{-/-}$mice behaved against joint inflammation. Moreover, Miki-Hosokawa et $\mathrm{al}^{35}$ found that $\mathrm{CD} 69^{-/}$mice inhibited lung inflammation by reducing the migration of $\mathrm{Th} 2$ cells. All these results suggested that CD69 might be a pro-inflammatory molecule in diseases' pathological progression.

Furthermore, we detected the frequency of $\mathrm{CD} 4^{+} \mathrm{CD}$ $25^{-} \mathrm{CD} 69^{+}$subsets. The percentage of the $\mathrm{CD} 4^{+} \mathrm{CD}$ $25^{-} \mathrm{CD}^{+} 9^{+}$subset showed a decreasing trend with DG 

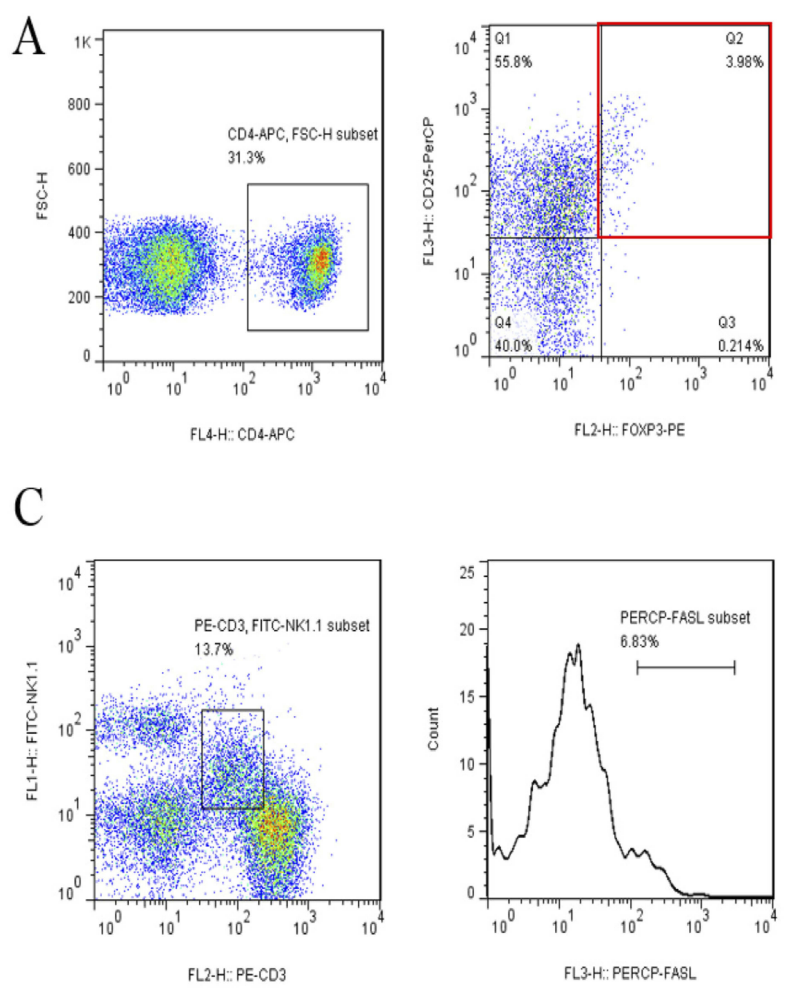

$\mathrm{B}$
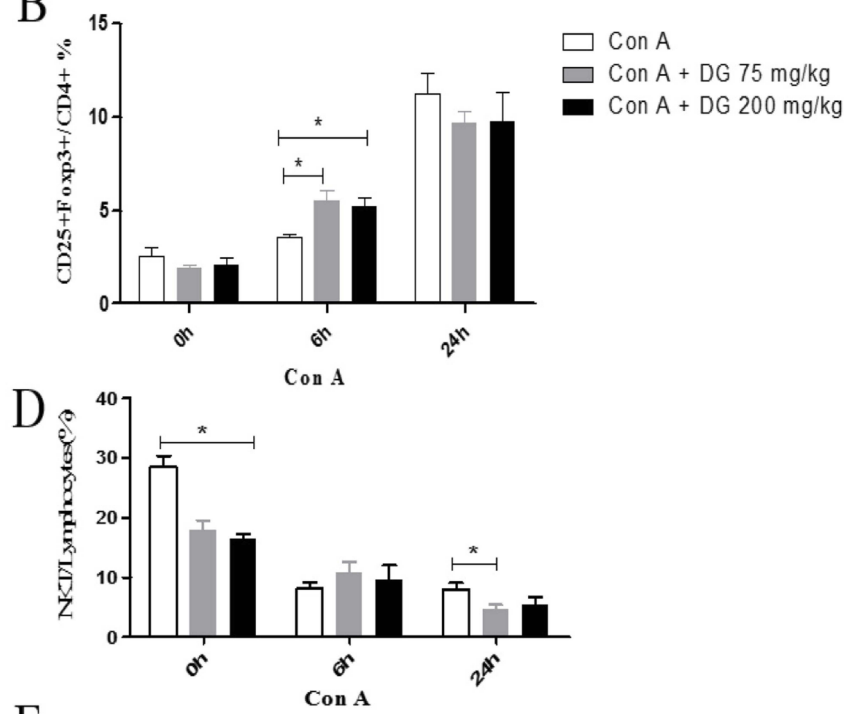

$\mathrm{E}$

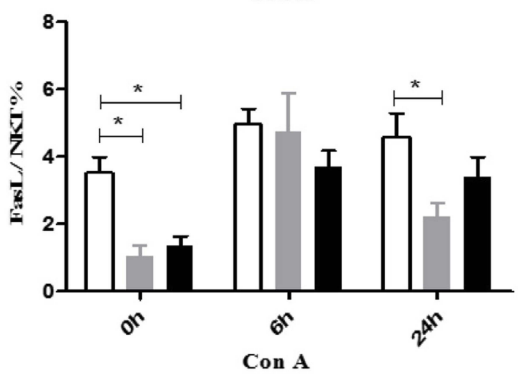

Figure 6 Pre-treatment with DG infected the frequencies of CD4 ${ }^{+} \mathrm{CD} 25^{+}$Foxp $3^{+}$Tregs and NKT cells in the livers in Con A challenged mice. (A) Analysis of Tregs in the liver. (B) The percentage of the Tregs subset from the liver in Con A-induced immune injury with or without DG pretreatment. (C) Analysis of NKT cells and expression of FasL on the surface of NKT cells in the liver. (D) The percentage of NKT cells from the liver in Con A-induced immune injury with or without DG pretreatment. (E) The percentage of FasL expressed on the surface of NKT cells from the liver in Con A-induced immune injury with or without $D G$ pretreatment. *means $P<0.05$. N $=8$ for each group. This experiment was performed in triplicate.

pretreatment compared with only Con A administration. The $\mathrm{CD} 4^{+} \mathrm{CD} 25^{-} \mathrm{CD} 69^{+}$subset was first proposed in Han et al's study, ${ }^{36}$ where $\mathrm{CD} 4^{+} \mathrm{CD} 25^{-} \mathrm{CD} 69^{+}$was described as a new type of Tregs and characterized by the negative expression of Foxp3 and IL-10, and it exerted a suppression effect in a cellcell contact manner mediated by membrane-bound TGF- $\beta 1$. However, the function of this subset needs to be clarified. Zhao et $\mathrm{al}^{37}$ reported that $\mathrm{CD} 4^{+} \mathrm{CD} 25^{-} \mathrm{CD} 69^{+}$was involved in leukemia relapse after hematopoietic stem cell transplantation. Gragegriebenow et $\mathrm{al}^{38}$ found that $\mathrm{CD} 4^{+} \mathrm{CD} 25^{-} \mathrm{CD} 69^{+}$ might induce tumor immune escape in pancreatic ductal adenocarcinoma, which contributes to carcinoma progression. A similar result appeared in granulocyte colony-stimulating factor (G-CSF)-primed bone marrow grafts, in which the $\mathrm{CD} 4^{+} \mathrm{CD} 25^{-} \mathrm{CD} 69^{+}$subset showed a high frequency, which may account for severe graft-versus-host disease. ${ }^{39}$ Although further mechanism needs to be confirmed, we can speculate that the $\mathrm{CD} 4^{+} \mathrm{CD} 25^{-} \mathrm{CD} 69^{+}$subset may be an important trigger in tumor and immune response, and its enrichment could break or aggravate immune homeostasis. Our data presented a lower percentage of the $\mathrm{CD} 4^{+} \mathrm{CD} 25^{-} \mathrm{CD} 69^{+}$subset in the Con A + DG administration group compared with the group that accepted Con A administration alone. In this regard, we concluded that a lower frequency of $\mathrm{CD} 4^{+} \mathrm{CD} 25^{-} \mathrm{CD} 69^{+}$may contribute to the protective effect of DG in Con A-induced liver injuries.

The imbalance between the effector and regulatory cells in the immune system is known as a crucial trigger for autoimmune responses. ${ }^{8,12}$ NKT cells are abundant in liver tissues, and several studies have indicated that NKT cells contributed to liver damage as a type of effector cells. ${ }^{8-12,40}$ Alisan Kahraman et $\mathrm{al}^{41}$ indicated that NK1.1-positive NK/ NKT cells accelerated the cholestatic liver injury by depending on a tumor necrosis factor-related apoptosisinducing ligand (TRAIL) pathway. While Tregs play an important anti-inflammation role in immune responses. Our results showed that DG pretreatment promoted $\mathrm{CD} 4^{+} \mathrm{CD} 25^{-} \mathrm{CD} 69^{+}$and $\mathrm{CD} 4^{+} \mathrm{CD} 25^{+} \mathrm{Foxp}^{+}$Tregs proliferation while inhibiting NKT cells proliferation, which indicated DG pretreatment protected liver injury by 
influencing the imbalance between effector and regulatory cells. Other studies have also reported that NKT cells and Tregs may antagonize each other in asthma. ${ }^{12}$

There were four limitations to our study. First, the protective role of DG in primary hepatocytes was not detected in vitro; second, the molecular mechanism of lymphocyte differentiation and apoptosis development still needs further clarification; third, the molecular mechanism of protective effect of DG needs further detection; fourth, the reaction between nonspecific immunecytes and Con A-induced hepatic injury was not detected.

In conclusion, the potential protective effect of DG against Con A-induced hepatitis may be partially attributed to its inhibitory activity on inflammatory cytokines in the livers, lymphocytes apoptosis in the thymus, NKT cells proliferation, and activation of $\mathrm{CD}^{+} \mathrm{T}$ cells. In addition, its promoting activity on Tregs proliferation may be involved.

\section{Abbreviations}

AIH, autoimmune hepatitis; ALT, alanine aminotransferase; AST, aspartate aminotransferase; Con A, concanavalin A; DG, diammonium glycyrrhizinate; PBMC, peripheral blood mononuclear cell; Tregs, regulatory $\mathrm{T}$ cells.

\section{Acknowledgments}

This work was supported by the Capital Foundation for Clinical Characteristic Applied Research Projects [Number Z181100001718084]; the Digestive Medical Coordinated Development Center of Beijing Hospitals Authority [Number XXZ0404]; National Natural Science Foundation of China [Number 81271901]; and Beijing Natural Science Foundation [Number 7152073].

\section{Disclosure}

The authors declare no conflicts of interests in this work.

\section{References}

1. Yuksel M, Wang Y, Tai N, et al. A novel "humanized mouse" model for autoimmune hepatitis and the association of gut microbiota with liver inflammation. Hepatology. 2015;62(5):1536-1550. doi:10.1002/hep.27 998

2. de Boer YS, van Gerven NM, Zwiers A, et al. Genome-wide association study identifies variants associated with autoimmune hepatitis type 1 . Gastroenterology. 2014;147(2):443-452. doi:10.1053/j.gastro.2014.04.0 22

3. Kirstein MM, Seibel E, Manns MP, et al. Prediction of short- and longterm outcome in patients with autoimmune hepatitis. $J$ Hepatol. 2015;62(5):1524-1535. doi:10.1002/hep.27983

4. Wang QX, Yan L, Ma X. Autoimmune hepatitis in the Asia-Pacific area. J Clin Transl Hepatol. 2018;6(1):48-56. doi:10.14218/JCTH. 2017.00032
5. Heneghan MA, Yeoman A, Verma S, Smith AD, Longhi MS. Autoimmune hepatitis. Lancet. 2013;382:1433-1444. doi:10.1016/ S0140-6736(12)62163-1

6. Ikeda A, Aoki N, Kido M, et al. Progression of autoimmune hepatitis is mediated by IL-18-producing dendritic cells and hepatic CXCL9 expression in mice. Hepatology. 2014;60:224-236. doi:10.1002/ hep. 27087

7. Liberal R, Grant CR, Yuksel M, et al. Treg conditioning endows activated teff with suppressor function in autoimmune hepatitis/autoimmune sclerosing cholangitis. Hepatology. 2017;66(5):1570-1584. doi:10.1002/hep. 29307

8. Wang H, Yin S. Natural killer T cells in liver injury, inflammation and cancer. Expert Rev Gastroenterol Hepatol. 2015;9(8):1077-1085. doi:10.1586/17474124.2015.1056738

9. Bhattacharjee J, Kirby M, Softic S, et al. Hepatic natural killer T-cell and CD8+ T-cell signatures in mice with nonalcoholic steatohepatitis. Hepatol Commun. 2017;1(4):299-310. doi:10.1002/hep4.1041

10. Wolf M, Adili A, Piotrowitz K, et al. Metabolic activation of intrahepatic CD8+ T cells and NKT cells causes nonalcoholic steatohepatitis and liver cancer via cross-talk with hepatocytes. Cancer Cell. 2014;26(4):549-564. doi:10.1016/j.ccell.2014.09.003

11. Zheng W, Du S, Tian M, et al. Lepidium meyenii walp exhibits antiinflammatory activity against ConA-induced acute hepatitis. Mediators Inflamm. 2018;2018:8982756. doi:10.1155/2018/8982756

12. Lu Y, Guo Y, Xu L, Li Y, Cao L. Foxp3 regulates ratio of Treg and NKT cells in a mouse model of asthma. Mol Cell Biochem. 2015;403 (1-2):25-31. doi:10.1007/s11010-015-2333-2

13. Shi HJ, Song HB, Wang L, Xiao S-X, Bo K-P, Ma W. The synergy of diammonium glycyrrhizinate remarkably reduces the toxicity of oxymatrine in ICR mice. Biomed Pharmacother. 2018;97:19-25. doi:10.1016/j.biopha.2017.09.039

14. Zhu X, Chen C, Ye D, et al. Diammonium glycyrrhizinate upregulates PGC- $1 \alpha$ and protects against A $\beta 1-42$-induced neurotoxicity. PLoS One. 2012;7(4):e35823. doi:10.1371/journal.pone.0035823

15. Jin J, Xiong T, Hou X, et al. Role of Nrf2 activation and NF- $\mathrm{kB}$ inhibition in valproic acid induced hepatotoxicity and in diammonium glycyrrhizinate induced protection in mice. Food Chem Toxicol. 2014;73:95-104. doi:10.1016/j.fct.2014.08.009

16. Orlent $\mathrm{H}$, Hansen BE, Willems $M$, et al. Biochemical and histological effects of 26 weeks of glycyrrhizin treatment in chronic hepatitis C: a randomized phase II trial. $J$ Hepatol. 2006;45(4):539-546. doi:10.1016/j.jhep.2006.05.015

17. Wang H, Fang ZZ, Meng R, et al. Glycyrrhizin and glycyrrhetinic acid inhibits alpha-naphthyl isothiocyanate-induced liver injury and bile acid cycle disruption. Toxicology. 2017;386:133-142. doi:10.1016/j.tox.2017. 05.012

18. Y W L, Hu YH, Zhu TT, Chu AZ, Zhu CL. Clinical efficacy of compound glycyrrhizin tablets in the treatment of children with nonalcoholic fatty liver disease. Zhongguo Dang Dai Er Ke Za Zhi. 2017;19(5):505-509.

19. Sun X, Duan X, Wang C, et al. Protective effects of glycyrrhizic acid against non-alcoholic fatty liver disease in mice. Eur J Pharmacol. 2017;806:75-82. doi:10.1016/j.ejphar.2017.04.021

20. Yasui S, Fujiwara K, Tawada A, Fukuda Y, Nakano M, Yokosuka O. Efficacy of intravenous glycyrrhizin in the early stage of acute onset autoimmune hepatitis. Dig Dis Sci. 2011;56(12):3638-3647. doi:10.1007/s10620-011-1789-5

21. Zhang X, Yang H, Yue S, et al. The mTOR inhibition in concurrence with ERK1/2 activation is involved in excessive autophagy induced by glycyrrhizin in hepatocellular carcinoma. Cancer Me. 2017;6 (8):1941-1951. doi:10.1002/cam4.1127

22. Li H, Guo D, Zhang L, Feng X. Glycyrrhizin attenuates histaminemediated MUC5AC upregulation, inflammatory cytokine production, and aquaporin 5 downregulation through suppressing the NF- $\mathrm{KB}$ pathway in human nasal epithelial cells. Chem Biol Interact. 2018;285:21-26. doi:10.1016/j.cbi.2018.02.010 
23. Zhao X, Liu J, Yang S, et al. Diammonium glycyrrhizinate alleviates hepatopulmonary syndrome, via, restoring superoxide dismutase 3 activity in rats. Eur J Pharmacol. 2017;807:144-150. doi:10.1016/j. ejphar.2017.04.025

24. Lei W, Huihui D, Yibo L, et al. Chinese medicine $\mathrm{Bu} \mathrm{Xu} \mathrm{Hua} \mathrm{Yu}$ recipe for the regulation of Treg/Th17 ratio imbalance in autoimmune hepatitis. Evid Based Complement Alternat Med. 2015;2015(3):1-14. doi:10.1155/2015/459749

25. Taubert R, Hardtke-Wolenski M, Noyan F, et al. Intrahepatic regulatory $\mathrm{T}$ cells in autoimmune hepatitis are associated with treatment response and depleted with current therapies. J Hepatol. 2014;61 (5):1106-1114. doi:10.1016/j.jhep.2014.05.034

26. González-Amaro R, Cortés JR, Sánchez-Madrid F, Martín P. Is CD69 an effective brake to control inflammatory diseases? Trends Mol Med. 2013;19(10):625-632. doi:10.1016/j.molmed.2013.07.006

27. Knodell RG, Ishak KG, Black WC, et al. Formulation and application of a numerical scoring system for assessing histological activity in asymptomatic chronic active hepatitis. Hepatology. 1981;1(5):431435. doi:10.1002/hep.1840010511

28. Park J, Kim H, Lee IS. The therapeutic effects of Yongdamsagantang on autoimmune hepatitis models. Biomed Pharmacother. 2017;94:244-255. doi:10.1016/j.biopha.2017.07.015

29. W W L, J Y Y, H L X, Bao J-K. Concanavalin A: a potential antineoplastic agent targeting apoptosis, autophagy and anti-angiogenesis for cancer therapeutics. Biochem Biophys Res Commun. 2011;414 (2):282-286. doi:10.1016/j.bbrc.2011.09.072

30. Burger ML, Leung KK, Bennett MJ, Winoto A. T cell-specific inhibition of multiple apoptotic pathways blocks negative selection and causes autoimmunity. ELife. 2014;3(3):e03468. doi:10.7554/eLife.03468

31. Cortés JR, Sánchez-Díaz R, Bovolenta ER, et al. Maintenance of immune tolerance by Foxp3+ regulatory T cells requires CD69 expression. J Autoimmun. 2014;55(1):51-62. doi:10.1016/j.jaut.2014.05.007

32. García-Monzón C, Moreno-Otero R, Pajares JM, et al. Expression of a novel $\mathrm{T}$ cell activation antigen on intrahepatic CD8+ T lymphocytes in viral chronic active hepatitis. Gastroenterology. 1990;98(4):1029 1035. doi:10.1016/0016-5085(90)90030-5
33. Hilda A, Roy-O'Reilly M, Spychala MS, et al. Sex differences in adipose tissue cd $8+\mathrm{t}$ cells and regulatory $\mathrm{t}$ cells in middle-aged mice. Front Immunol. 2018;9:659. doi:10.3389/fimmu.2018.00659

34. Murata K, Inami M, Hasegawa A, et al. CD69-null mice protected from arthritis induced with anti-type II collagen antibodies. Int Immunol. 2003;15(8):987-992. doi:10.1093/intimm/dxg008

35. Miki-Hosokawa T, Hasegawa A, Iwamura C, et al. CD69 controls the pathogenesis of allergic airway inflammation. J Immunol. 2009;183 (12):8203-8215. doi:10.4049/jimmunol.0900838

36. Han Y, Guo Q, Zhang M, Chen Z, Cao X. CD69+ CD4+ CD25- T cells, a new subset of regulatory $\mathrm{T}$ cells, suppress $\mathrm{T}$ cell proliferation through membrane-bound TGF- $\beta 1$. J Immunol. 2009;182(1):111120. doi:10.4049/jimmunol.182.1.111

37. Zhao XS, Wang XH, Zhao XY, et al. Non-traditional CD4+ CD25$\mathrm{CD} 69+$ regulatory $\mathrm{T}$ cells are correlated to leukemia relapse after allogeneic hematopoietic stem cell transplantation. J Transl Med. 2014;12(1):187. doi:10.1186/1479-5876-12-187

38. Grage-Griebenow E, Jerg E, Gorys A, et al. L1CAM promotes enrichment of immunosuppressive T cells in human pancreatic cancer correlating with malignant progression. Mol Oncol. 2014;8(5):982997. doi:10.1016/j.molonc.2014.03.001

39. Zhao XY, Wang YT, Mo XD, et al. Higher frequency of regulatory $T$ cells in granulocyte colony-stimulating factor (G-CSF)-primed bone marrow grafts compared with G-CSF-primed peripheral blood grafts. $J$ Transl Med. 2015;13(1):145. doi:10.1186/s12967-015-0541-x

40. Kumar V. NKT-cell subsets: promoters and protectors in inflammatory liver disease. J Hepatol. 2013;59(3):618-620. doi:10.1016/j. jhep.2013.02.032

41. Kahraman A, Barreyro FJ, Bronk SF, et al. TRAIL mediates liver injury by the innate immune system in the bile duct-ligated mouse. Hepatology. 2008;47(4):1317-1330. doi:10.1002/hep.22136
Drug Design, Development and Therapy

\section{Publish your work in this journal}

Drug Design, Development and Therapy is an international, peerreviewed open-access journal that spans the spectrum of drug design and development through to clinical applications. Clinical outcomes, patient safety, and programs for the development and effective, safe, and sustained use of medicines are a feature of the journal, which has also been accepted for indexing on PubMed Central. The manuscript management system is completely online and includes a very quick and fair peer-review system, which is all easy to use. Visit http://www. dovepress.com/testimonials.php to read real quotes from published authors. 